\title{
Konrad Sierzputowski
}

\author{
Uniwersytet Jagielloński \\ Wydział Polonistyki \\ Katedra Antropologii Literatury i Badań Kulturowych
}

\section{AUDIO-SOMA-WIZUALNOŚĆ. CIAŁO W RELACJI Z OBIEKTEM AUDIOWIZUALNYM}

\section{Audio-soma-visuality. Body in relation with audio-visual object}

\begin{abstract}
Dichotomy between visual and acoustic culture is fiction and as a result of that thinking, we can find concept of neutral audio-visuality - idea which is bonding the two semantic fields: audio and visual. Unfortunately, this idea is only an illusion than actual practice. An attempt to analyze the experience of only one perspective pictorial or sound, is only epistemic misapprehension. Contemporary artists prove us how complex is this experience and how to continually moved the boundary between what is visual, what is only audio and what kind of utopia can be audio-visuality. Their projects hit directly in the monumental division between where located is body, sound and images in our experience. Musicians such as Peter Ablinger (Deus Cantando), Dmitry Morozov (Reading My Body), or artistic group Pendulum Choir are best examples of new kind of audio-soma-visality experiments. Their musical projects and objects involves perceptual and bodily sensations, thereby opening classically understood sensorium to a whole new dimension of experience. They put body as a figure that is necessary to bond and fill the gap between the language of sounds and language of images.
\end{abstract}

Keywords: body, audiovisuality, perception, sound, voice

\section{Wstęp. Ciało Glenna Goulda}

Historia muzyki zachodniej to historia napięć i paradoksów. Znajdziemy w niej wspaniałe utwory oraz prześledzimy rozwój form i gatunków muzycznych, ale na równych prawach odkryjemy także opowieści o genialnych dzieciach, głuchych kompozytorach i nienawistnych pojedynkach między artystami i krytykami. Historycy muzyki i biografowie kompozytorów ochoczo ukazują pęknięcia i ludzki aspekt każdego napotkanego przejawu geniuszu. Oprócz wprowadzenia elementu 
anegdotycznego skutkuje to również poszerzeniem interpretacji aktywności artystycznej w danej epoce o wyciszone do tej pory elementy. Jednym z nich jest niewątpliwie ciało wykonawcy i odbiorcy. Za idealny przykład takiej refleksji somatycznej można uznać Glenna Goulda - jednego z najważniejszych XX-wiecznych muzyków. Wystarczy przysłuchać się Wariacjom Goldbergowskim w wykonaniu Goulda z 1981 roku, by zrozumieć, że to nie tylko obcowanie ze współczesnym wykonaniem i interpretacją kompozycji Bacha, to także spotkanie z ciałem lub też śladem ciała pianisty. Pierwsze dźwięki arii z wariacji obarczone są jego obecnością, jego oddechem i cielesnym naddatkiem w postaci dźwięków, „dośpiewywanych” do utworu. Dźwięków, które nie ustaną wraz z zakończeniem pierwszej podstawowej części, a które będą trwać w czasie kolejnych trzydziestu wariacji. Najbardziej interesujące jest jednak to, że Gould fizyczne obcowanie ze słuchającą publicznością oraz ślad obecności człowieka w formie muzycznej uważał za rodzaj skażenia i świętokradztwa ${ }^{1}$. O specyfice cielesnej pianisty pisał m.in. Stefan Rieger. Jak zauważa autor monografii poświęconej kanadyjskiemu artyście, jego (nie)obecność miała szczególny charakter śladu:

Słuchając większości nagrań Goulda, stykamy się z trudno wytłumaczalnym paradoksem „obecności - nieobecności” w maksymalnym stężeniu. Kiedy gra ktoś inny, za polem magnetycznym muzyki czujemy żywego człowieka, czasem nawet słyszymy bardziej tego człowieka niż muzykę. Ale przecież Gould jest fizycznie obecny jeszcze intensywniej. Daje znać o swojej obecności nie tylko skrzypiącym krzesełkiem, nie tylko nieodłącznym mruczandem - lecz również natychmiast rozpoznawalną artykulacją, niepodobnym do niczego brzmieniem, elektrycznym natężeniem frazy... A mimo to trudno oprzeć się wrażeniu, że go nie ma. Tylko krzesełko i śpiew przypominają - nadaremnie - o jego istnieniu ${ }^{2}$.

Glenn Gould jest tylko jednym z wielu ,trudnych do sklasyfikowania” muzyków, którzy (czy to z pełną intencją, czy też całkowicie przypadkowo) problematyzują kwestię somatyczności wykonawcy w kontekście relacji z odbiorcą, opierając się na paradoksalnej relacji obecne - nieobecne, wskazując, że ślad ciała jest tylko niezbędną autorską inskrypcją ${ }^{3}$.

\section{Nieodparta potrzeba ciała. Somatyczność a audiowizualność}

Blisko czterdzieści lat po wydaniu drugiej wersji Wariacji Goldbergowskich oraz eseju The Prospects of Recording problem cielesności wykonawcy i muzyki, zwłaszcza w kontekście relacji z odbiorcą, nie został całkowicie wyeksploatowany. Dyskurs ten poszerzono o nowe elementy, które stawiają wiele pytań o kwestię audiowizualności wykonań oraz tego, jak w nowe poetyki (czy też relacje dźwiękowo-obrazowe

Por. S. Rieger, Glenn Gould, czyli sztuka fugi, Gdańsk 1997, s. 23 i 38.

Ibidem, s. 51.

Zob. G. Gould, The Prospects of Recording, w: Glenn Gould Reader, New York 1984. 
oraz te angażujące inne zmysły) może zostać wprowadzone sensorium podmiotu. Jak komentuje tę kwestię teatrolożka Agnieszka Jelewska:

Współczesny relacyjny paradygmat rzeczywistości rekontekstualizuje poziomy rozumienia zjawisk; wraz z tym procesem stajemy wobec konieczności uchwycenia dynamicznych i właściwie nie kończących się procedur konstytuowania się podmiotu poznającego ${ }^{4}$.

Podmiot poznający, uwikłany w sytuację angażującą całe sensorium, staje przed trudem poznawczym, którego potencjału nie wyczerpie analiza wyłącznie z perspektywy wizualnej lub dźwiękowej. Jak ujął to Jakub Momro: „Słuchanie i słyszenie są zupełnie innymi aktywnościami podmiotu niż widzenie i patrzenie, mimo że chcielibyśmy je widzieć w »audiowizualnej« jedności"5. Podmiot w tym rozumieniu nie jest jednak kartezjański, rozdzielny pod względem duszy i ciała. By sproblematyzować tę interesującą kwestię, do dubletów: słuchanie i słyszenie oraz widzenie i patrzenie dodajmy element ciała słuchacza i ciała wykonawcy. Dlatego też kolejnym krokiem powinna być dekonstrukcja triady: podmiot - dźwięk - obraz oraz pojęcia audiowizualność. Koniecznym elementem wydaje się więc ciało: wspólny, choć tylko domyślny, mianownik obrazu i dźwięku6. Różnice pomiędzy aktem recepcji audialnej i piktoralnej wytworzyły potrzebę ustanowienia dychotomicznego podziału na kulturę wizualną i akustyczną. Podział ten uważany jest jednak za imaginacyjny, niewystarczający, krzywdzący, a także fałszywy; mimo to nadal pozostaje silnie hegemoniczny. Oczywiście, w myśleniu o kulturze dźwięku i kulturze obrazu nastąpiły momenty przełomowe, co już dawno zaowocowało wykrystalizowaniem się pojęcia (w założeniu) neutralnego i spajające oba pola semantyczne, mianowicie audiowizualność. Niestety i ta idea stanowi częściej fantasmagorię niż rzeczywistą praktykę w namyśle nad fenomenami kultury najnowszej.

Separacja widza od sceny za pośrednictwem medium-nośnika doprowadziła do rozdzielenia tego, co słyszalne, od tego, co wyłącznie oddane oku, co jest skutkiem

A. Jelewska, Sensorium. Eseje o sztuce i technologii, Poznań 2012, s. 15.

J. Momro, Fenomenologia ucha, „Teksty Drugie” 2015, nr 5, s. 10.

6 Zaznaczam, że interesuje mnie przede wszystkim relacja pomiędzy „uchem i okiem”, traktowanymi jako domniemane, prymarne „narzędzia” zmysłowe. To one bowiem wykorzystywane są (z założenia) do percepcji zjawisk audiowizualnych. Rezygnacja $\mathrm{z}$ aspektów związanych z pozostałymi zmysłami przy opisie zjawisk audiowizualnych jest działaniem zamierzonym. Zdaję sobie sprawę z potencjalnych zarzutów dotyczących tej redukcji sensoralnej. Na potrzeby niniejszego tekstu chciałbym skupić się na audiowizualności w jej aspektach zawartych w zakresie samej nazwy, czyli przede wszystkim elementach audialnym i wizualnym. Kwestia, która interesuje mnie najbardziej, dotyczy tego, jak dodanie ciała, jako narzędzia doświadczania świata, może sproblematyzować akt symultanicznej percepcji dźwięku i obrazu. Dlatego też w niniejszym artykule skupiam się wyłącznie na relacji pomiędzy ciałem, dźwiękiem i obrazem. Uważam przy tym, że dodanie elementu somatycznego, jako spoiwa obu aspektów audiowizualnych, jest propozycją otwartą. Może to pomóc w rozszerzaniu analizy tekstów kultury o kolejne elementy angażujące pozostałe zmysły. Jest to jednak praca, która przede wszystkim znacząco wykracza poza temat niniejszego artykułu. Uważam także, że wypadałoby kwestię tę przeanalizować jak najdokładniej. Dlatego też z pełną świadomością rezygnuję z tego zadania, przede wszystkim, by uniknąć dezynwoltury i pośpiechu w namyśle i interpretacji innych zjawisk kultury. 
XX-wiecznej reprodukcji technicznej’. Historia kultury zachodniej pokazuje, że teksty kultury (w pierwszej kolejności) ulegają władzy spojrzenia podmiotu, a oparte na nim sądy egzystencjalne i predykatywne ${ }^{8}$ tylko częściowo dopełniają kulturowe episteme jednostki. Doświadczenie dopełniane jest (jeżeli w ogóle) wrażeniami dźwiękowymi nierównomiernie i to dopiero w drugiej kolejności. Uznanie tego stanu za niewystarczający rodzi potrzebę angażowania innych zmysłów i form percepcji, które dodatkowo uwydatnić mogą aspekty taktylne i olfaktoryczne danego zjawiska. Porządek percepcji jawi się jako naturalny, jest bowiem oparty na skracaniu dystansu - od oka do dotyku. Naturalizacja tego procesu wydaje się jednak efektem okulocentryczności kultury zachodniej. Co interesujące, pomimo rozwoju antropologii zmysłów oraz dyscyplin bazujących na wielozmysłowości oraz studiów porównawczych nad systemami sensorycznymi w różnych kulturach świata, nadal to okcydentalny wzrok pozostaje zmysłem uprzywilejowanym ${ }^{9}$. Korzystając jednak $z$ tego stanu rzeczy i skupiając się wyłącznie na aspekcie wizualnym i audialnym, da się zauważyć, że symultaniczne ujęcie obu aspektów badanego zjawiska jest niezwykle trudne. Opisanie konglomeratu tych cech jest praktycznie niemożliwe, bowiem o polu dźwiękowym i obrazowym nie da się mówić na tym samym poziomie. Języki obu aspektów są niekoherentne, a przez to trudne do swobodnego manewrowania teoretycznego. Doprowadza to do sytuacji, w której mówimy o obrazie i dźwięku w trybie implikacji, gdzie to zazwyczaj obraz stanowi punkt nadrzędny. Nie ma tu mowy o koniunkcji, gdzie to dźwięk byłby uprzywilejowany wobec obrazu, któremu towarzyszy ${ }^{10}$. Problem ten zauważył m.in. Jonathan Sterne, krytycznie odnosząc się do historii kultury zachodniej opisywanej z perspektywy wyłącznie wizualnej:

Por. W. Benjamin, Twórca jako wytwórca, przeł. R. Reszke, Warszawa 2011.

8 Por. E. Husserl, Doświadczenie $i$ sąd: badania nad genealogia logiki, przeł. B. Baran, Warszawa 2013.

9 Antropologia zmysłów oraz inne dyscypliny wykorzystujące sensorium do prowadzenia porównawczych badań nad zjawiskami kulturowymi różnych regionów świata od lat wypracowują narzędzia pomagające zrezygnować z oka jako podstawowego zmysłu badawczego i głównego narzędzia badacza. Jak dodaje Agata Stanisz: „Oczywiście okulocentryzm oraz wizualność w antropologii nadal mają się znakomicie, pomimo że dyscyplina ma współcześnie do dyspozycji wiele narzędzi pozwalających na praktyczną realizację postulatu wielozmysłowości, a także zmniejszenie nacisku położonego na wzrokocentryzm badań etnograficznych oraz ewaluację projektów naukowych" (Audioantropologia: praktykowanie dyscypliny poprzez dźwięk, „Zeszyty Naukowe Uniwersytetu Jagiellońskiego MCCCXXXVI. Prace Etnograficzne" 2014, t. 42, z. 4, s. 306). Analizy antropologów wykazały, że podstawowy zmysł wykorzystywany do percepcji rzeczywistości jest uzależniony od wielu aspektów społecznych oraz udoskonaleń technicznych, które przyzwyczajają uczestnika życia społecznego do korzystania ze zmysłów w „określonym” porządku. Na potrzeby tego tekstu zajmę się wyłącznie perspektywą i zachodnim porządkiem sensorycznym, jednak zainteresowanych antropologią zmysłów oraz innymi systemami hierarchii zmysłów odsyłam przede wszystkim do prac Davida Howesa: D. Howes, A Cultural History of the Senses in the Modern Age, 1920-2000, London-New York 2014; idem, Sensual Relations: Engaging the Senses in Culture and Social Theory, Ann Arbor 2003.

10 Czego przykładem jest choćby tekst Pierre’a Schaeffera o akuzmatach, czyli dźwiękach, których przyczyny nie możemy odnaleźć. Schaeffer, pomimo że pisze o dźwiękach, to nieustannie, a nie- 
Istnieje zawsze więcej niż jedna mapa dla danego terytorium, a dźwięk unaocznia istnienie innej szczegółowej ścieżki w historii kultury. W niektórych przypadkach współczesne sposoby słuchania poprzedziły wszak nowoczesne techniki widzenia ${ }^{11}$.

W tej złożonej geografii percepcji swoje prace lokują muzycy, którzy od lat starają się podważać binarny system dźwięk - obraz z wykorzystaniem narzędzia, jakim jest ciało. Jak pisał o nim Maurice Merleau-Ponty, jeden z głównych twórców XX-wiecznej refleksji somatycznej, ,ciało jest naszym ogólnym sposobem posiadania świata"12. Francuski teoretyk wprost pisze o nadrzędnej funkcji ciała w codziennym doświadczaniu rzeczywistości:

Ciało konstytuuje podstawowy i zasadniczy wymiar naszej tożsamości (...). Ciało wyraża dwuznaczność istoty ludzkiej, będącej subiektywną wrażliwością doświadczającą świata, a zarazem postrzeganym $w$ tym świecie przedmiotem (...). To właśnie z niego i poprzez nie sięgam lub poruszam przedmiotami, na których jestem skupiony, lecz nie ujmuję ciała jako wyraźnego obiektu świadomości, nawet jeśli je odczuwam jako kontekstowy warunek percepcji ${ }^{13}$.

Dla Merleau-Ponty’ego ciało jest wyłączną możliwością poznawania rzeczywistości. To jedyne narzędzie podmiotu, dzięki któremu (a przede wszystkim, przez które) filtrowane jest ludzkie doświadczenie. Ciało zawsze pozostaje w relacji z innymi obiektami, i co najważniejsze, samo jest także obiektem w przestrzeni. Podmiot może nieustannie poszerzać własny schemat cielesny dzięki doświadczaniu relacji z innymi ciałami i obiektami ${ }^{14}$. Patrzenie i wsłuchiwanie się w przedmioty, które znajdują się w określonej sytuacji w polu lub też w zakresie naszej percepcji, to możliwość konstytuowania własnej podmiotowości, ale także usensownianie percypowanych obiektów. Zadaniem fenomenologii percepcji jest zatem badanie wszystkich możliwych konfiguracji potencjalnych i danych relacji somatycznych oraz ich wpływu na ludzkie doświadczenie rzeczywistości i podmiotowe usytuowanie w przestrzeni tego doświadczenia. Metodologia wypracowana w Fenomenologii percepcji (pomimo ponad siedemdziesięciu lat od publikacji pierwszego wydania) nadal pozostaje jednym z podstawowych aparatów teoretycznych, stosowanym w badaniach nad postrzeganiem i doświadczeniem cielesnym, a wpływy myśli Merleau-Ponty’ego odnaleźć można w wielu współczesnych pracach teo-

kiedy schizofrenicznie, próbuje odnaleźć ich źródło. Bez przerwy do niego powracając i szukając jego właściwości, mimo że znajduje się ono poza zasięgiem percepcji. Dźwięk jest efektem, co oznacza, że jest wynikiem jakiejśs sytuacji. Zob. P. Schaeffer, Akuzmatyka, w: C. Cox, D. Warner, Kultura dźwięku. Teksty o muzyce nowoczesnej, przeł. J. Kutyła, Gdańsk 2010, s. 106-112.

11 J. Sterne, Audible Past: Cultural Origins of Sound Reproduction, London 2003, s. 3 (thum. własne).

12 M. Merleau-Ponty, Fenomenologia percepcji, przeł. M. Kowalska, J. Migasiński, Warszawa 2001, s. 166.

13 R. Shusterman, Świadomość ciała. Dociekania z zakresu somaestetyki, przeł. W. Małecki, S. Stankiewicz, Kraków 2010, s. 21-22.

14 Zob. M. Merlau-Ponty, Fenomenologia percepcji, op. cit., s. 88, 173. 
retycznych zajmujących się kwestią ciała w różnych jego aspektach ${ }^{15}$. Przytoczeni artyści audiowizualni wykorzystują (również krytycznie) propozycje francuskiego teoretyka. Stworzone przez nich obiekty problematyzują relację ciało-obiekt i pogłębiają percepcję przez trudne do klasyfikacji bodźce. Na potrzeby niniejszego tekstu wybrałem trzy prace, które są radykalnymi przejawami owej refleksji somatycznej, i które w interesujący sposób realizują założenia projektów badawczych o charakterze art-based $^{16}$. Są to kolejno: Peter Ablinger (praca Deus Cantando), Dimitrij Morozow (Reading My Body) i grupa artystyczna Pendulum Choir. Ich projekty pytają wprost o rolę ciała: zarówno wykonawcy, jak i odbiorcy widowiska. Problematyzują kwestię percepcji somatycznej i kognitywnych funkcji ciała. Prace przywołanych artystów na różnych poziomach i w zróżnicowany sposób ujmują kwestie wzajemnego powiązania audialności, wizualności i somatyczności, zarówno odbiorcy, jak i twórcy-muzyka. Dokonują przy tym dekonstrukcji pojęcia audiowizualność w jego klasycznym ujęciu. Udowadniają, że misja audiowizualności, jako „totalnej unifikacji wrażeniowości” podmiotu, być może jest jednak całkowicie fikcyjna. Rezygnuję tym samym z analizy przywoływanych prac z wykorzystaniem metodologii zastosowanej a priori i wybieram perspektywę interpretatora relacji cielesno-obiektowej, w jakiej znajduje się odbiorca. Wszystko to w celu zastanowienia się nad krytycznym charakterem tych dzieł. Każde z nich w zróżnicowany sposób przedstawia potencjalną sytuację ciała w relacji z obiektem audiowizualnym i konsekwencje poznawcze tej relacji.

\section{Bóg nas opuścił, lecz pozostawił głos?}

Wyobraźmy sobie obiekt: fortepian lub pianino splątane kablami i migające czerwonymi lampkami, które zaczyna grać dźwięki przypominające zniekształcony ludzki głos. Nad instrumentem wyświetlany jest tekst, który klawisze „odczytują”. Okazuje się, że instrument muzyczny „czyta” lub „recytuje” tekst manifestu. Materiał staje się całkowicie zrozumiały dla odbiorcy dopiero w kontekście relacji dźwięk-tekst. Nie jest to obiekt fikcyjny czy hipotetyczny, to opis działania konkretnej insta-

15 Wpływy fenomenologii percepcji możemy odnaleźć w najróżniejszych dziedzinach. Od badań kognitywnych (A. Noë, Action in Perception, Cambridge 2002) przez estetykę (A. Berleant, Wrażliwość i zmysty. Estetyczna przemiana świata człowieka, przeł. S. Stankiewicz, Kraków 2011) do teorii feministycznych (I.M. Young, Throwing Like a Girl: A Phenomenology of Feminine Body Comportment Motility and Spatiality, „Human Studies” 1980, nr 3).

16 Badania typu art-based definiowane są przez Shauna McNiffa jako: „systemowe użycie procesu artystycznego, czyli faktycznej ekspresji artystycznej we wszystkich zróżnicowanych formach sztuki, jako sposobu rozumienia i analizowania doświadczenia, zarówno przez badaczy, jak i ludzi zaangażowanych w projekty artystyczne [odbiorców tego dzieła - dop. K.S.]". S. McNiff, Art-Based Research, w: J.G. Knowles, A.L. Cole, Handbook of the Arts in Qualitative Research: Perspectives, Methodologies, Examples, and Issues, Thousand Oaks 2008, s. 29 (tłum. własne). 
lacji dźwiękowej ${ }^{17}$ autorstwa Winfrieda Ritscha z wykorzystaniem utworu (i pomysłu na cały projekt) Deus Cantando austriackiego eksperymentalnego kompozytora Petera Ablingera. Mamy tu do czynienia z udoskonaloną, w pewnym stopniu odrealnioną i zsekularyzowaną współczesną formą pianoli - „pianino, które gada”, jak napisał o nim propagator pojęcia muzyki relacyjnej Harry Lehmann:

Widzimy i słyszymy samogrający fortepian, imitujący ludzki głos. Kiedy nie zna się tekstu, na początku można uchwycić tylko pojedyncze skrawki słów, kiedy jednak przeczyta się, zgodnie z zaleceniem, treść wyświetlanej na ekranie deklaracji Międzynarodowego Trybunału przeciwko Zbrodniom na Środowisku, wtedy słychać każde słowo wypowiadane przez fortepian. Chociaż w kulturze rozumu tego rodzaju doświadczenie nie powinno mieć miejsca, pierwsze zetknięcie z gadającym fortepianem sprawia wrażenie $\mathrm{cudu}^{18}$.

Deus Cantando Ablingera wykorzystuje problematykę obecne-nieobecne w celu wytworzenia napięcia somatycznego ${ }^{19}$. Podważa ideę Schaefferowskiego podziału na akustykę (badanie źródła dźwięku) i akuzmatykę (interpretacja reakcji na bodziec dźwiękowy). Dźwięk akuzmatyczny jest strukturą, w której trudne lub niemożliwe jest zlokalizowanie obiektu, który ów dźwięk wytworzył²0 ale boskie pianino Ablingera problematyzuje tę kwestię znacząco: źródło dźwięku jest możliwe do dostrzeżenia i nazwania - to instrument muzyczny. Jednak ,głos”, czyli usemantyzowany dźwięk, jest już poza możliwością jednoznacznego określenia. Brak tu ciała, które mogłoby być źródłem głosu, jest jedynie instrument, który jest źródłem dźwięku. W innej perspektywie interpretacyjnej Deus Cantando to przedmiot, który „wydobywa głos” z nas, ale bez naszego uświadomionego i krytycznego udziału. Czy to oznaczałoby, że zaistniała sytuacja zmusza nas do stania się brzuchomówcami? Jeżeli tak, to w jaki sposób? O podobnym zjawisku pisał już teoretyk wizualności William Mitchell:

17 Prezentowanej również w Polsce w 2014 roku w ramach festiwalu teatralnego Malta Festival w Poznaniu.

18 H. Lehmann, Muzyka relacyjna, artykuł cyfrowy, źródło: www.rewolucjacyfrowa.beczmiana.pl.

19 Praca Ablingera nie jest projektem całkowicie innowacyjnym. Prace nad wczesnymi formami pianoli czy konceptu podobnego do Deus Cantando pojawiły się już w XVIII wieku. Królewska Akademia Nauk w Petersburgu w 1780 roku ogłosiła konkurs na stworzenie i zaprezentowanie automatu, który będzie potrafił reprodukować głoski, w celu wyjaśnienia zasady działania ludzkiego głosu; swoją propozycję przedstawił konstruktor Wolfgang von Kempeler. Jego die Spreche-Maschine, czyli drewniane pudełko zakończone z jednej strony skórzanym workiem („,płuca”), a z drugiej gumowym lejkiem (,usta”), potrafiło imitować całe zdania w kilku językach. Zasada była dość prosta: powietrze nabierane do skórzanego worka i wydmuchiwane przez kontrolowane gumowe usta wydostawało się razem z dźwiękiem - był to mechanizm zbliżony do ludzkiej aparatury mowy. Wydarzenie, jakim było usłyszenie ludzkiego głosu bez udziału człowieka, było freudowsko „niesamowite”. Jak donoszą wspomnienia z pokazu die Speche-Maschine: „Nie uwierzysz, mój przyjacielu, jak bardzo byliśmy opanowani tym magicznym uczuciem, gdy pierwszy raz usłyszeliśmy ludzki głos i ludzką mowę, które w widoczny sposób nie dochodziły z ludzkich ust. Spoglądaliśmy na siebie w milczeniu i konsternacji i wszyscy mieliśmy gęsią skórkę pod wpływem trwogi tego pierwszego momentu". Cyt. za: M. Dolar, Voice and Nothing More, Cambridge 2006, s. 7 (tłum. własne).

20 P. Schaeffer, Akuzmatyka, w: C. Cox, D. Warner, Kultura dźwięku..., op. cit., s. 106-112. 
Obraz nie jest tekstem przeznaczonym do czytania, lecz żołądkiem brzuchomówcy, w którym projektujemy własny głos. Gdy obraża nas to, co obraz „mówi”, jesteśmy niczym brzuchomówca obrażony przez własny brzuch. (...) niesamowitość brzucha, ,jego życie własnym życiem (i głosem)" jest podstawą gry brzuchomówstwa jako takiego. Głosu nie można po prostu wrzucić w nieożywiony przedmiot. Konieczne jest wrażenie, że przedmiot mówi własnym głosem. Prawdziwy brzuchomówca nie narzuca swojego głosu niemej rzeczy, lecz wyraża jej autonomię i wyjątkowość ${ }^{1}$.

Zastosowana przez Mitchella metafora brzuchomówcy odnosi się przede wszystkim do kwestii milczenia obrazów i ich niezdolności do obrażania widza (o co, jak pisze autor, są nieustannie oskarżane), metafora ta wydaje się niezwykle trafna i produktywna do opisu somatyczności dzieła Petera Ablingera. Wrażenie wywoływane przez Deus Cantando jest jednoznaczne: „to pianino mówi”. Wchodząc w relację z obiektem, tworzymy imaginacyjne fantomowe ciało. Źródłem głosu jest transcendentny, choć tak naprawdę pochodzący z nas deus: bożek, który mówi do nas, ale z samego źródła „nas”. Nie istnieje explicite, jest jedynie projektowany. Jako ciała jesteśmy niezbędni dla przedmiotu do uruchomienia machiny produkcji znaczenia. Deus Cantando jest brzuchomówcą, ale to my wchodzimy w rolę jego głosu. Obiekt jest tak sprawny w swoim działaniu, że udaje mu się tworzyć iluzję, że to podmiot pozostaje sprawczy i ma moc nadawania sensu. Relacja jest więc pasożytnicza; brak bio-obiektu (porządek stojący po stronie akuzmatyki) kusi dźwiękiem (wynikającym z akustyki), który ,przepoczwarza się” w fantomowe ciało, dla którego nasz głos i mowa są tylko efektem brzuchomówstwa - to nie podmiot percypujący jest aktorem przedstawienia. Odbiorcy pozostają pozbawieni indywidualizmu i reprodukują nieprzynależne do nich sensy w procesie percepcji. Nie można jednak rozdzielić doświadczenia na porządek oka i porządek ucha - boskie pianino splata je konsekwentnie w jeden strumień doświadczenia.

\section{Ciało czy instrument?}

Rosyjski muzyk i konstruktor - Dimitrij Morozow (występujący pod pseudonimem ::vtol::) - na przełomie 2013 i 2014 roku zaprezentował projekt: Reading My Body, który posługuje się poetyką ,fragmentu ciała”. To mechaniczny kontroler nakładany na ramię muzyka, który odczytuje kształty geometrycznego wzoru tatuażu („element” twórcy niezbędny do działania urządzenia), by następnie przekształcić pobrany materiał wizualny na odpowiednie wartości liczbowe, a te na konkretne elektroniczne dźwięki i w efekcie całą kompozycję. Druga ręka pomaga w nadzorowaniu procesu odczytu i przekształceń dźwiękowych. Kształt urządzenia może budzić skojarzenia z chordofonami, najbardziej jednak ze skrzypcami. W oficjalnym portfolio artysty znajdujemy niniejszą informację o Reading My Body:

21 W.J.T. Mitchell, Czego chca obrazy? Pragnienia przedstawień, życie i miłości obrazów, przeł. Ł. Zaremba, Warszawa 2015, s. 168-169. 
To specjalny instrument, który wiąże ludzkie ciało i robotyczny system w pojedynczy byt, który jest zaprojektowany do zautomatyzowanego procesu kreatywności - próby reprezentacji artysty i jego instrumentu jako kreatywnej hybrydy ${ }^{22}$.

Projektowi Rosjanina towarzyszy krytyczny namysł nad separacją ciała wykonawcy od instrumentu, którym się posługuje ${ }^{23}$. Zmiany w zakresie używania instrumentów muzycznych i ich relacji do posiadacza/użytkownika wynikają z rewolucji rejestracji dźwiękowej. Ciało wykonawcy - wirtuoza wyniesione na scenę w wyniku XIX-wiecznych wielkich koncertów i modnej w tym okresie koncepcji filozofii geniuszu, zostało odizolowane od dźwięków, które jest w stanie wytworzyć24 . Możliwość obcowania z samym dźwiękiem nagrania oddziela nas tym samym od jawnej somatyczności instrumentu muzycznego, będącego elementem (niebiologicznym) gestu performatywnego w muzyce ${ }^{25}$.

Przemiany technologiczne w zakresie rejestracji dźwięków doprowadziły do ukrycia ciała i jego towarzysza - instrumentu muzycznego. ::vtol:: udowadnia jednak, że nawet tak odległa od estetyki somatycznej muzyka elektroniczna (będąca, jako gatunek, również efektem technicznych udoskonaleń) może być na wskroś cielesna. Jego instrument jest obiektem wpisującym się w poetykę futurystycznych tekstów kultury z pogranicza cyber i dieselpunku, jest przy tym jednak głęboko zanurzony w historii wirtuozerii muzycznej (jedynie stylistycznie wprowadza powiew przyszłości). Wikła odbiorcę w spór o granicę pomiędzy ciałem i instrumentem oraz wprowadza kwestię genezy dźwięku. Stawia elementarne pytanie o to, czy muzyka jest wynikiem pracy ciała czy może pracy instrumentu? Nie daje oczywiście jednoznacznej odpowiedzi. Reading My Body jest urzeczywistnieniem idei (bio)audiowizualności, ale jest także grą o uznanie bądź odrzucenie koncepcji somatycznego źródła struktur dźwiękowych. Aspekty tego, co związane z obrazem (za co można uznać zarówno cały obiekt, ale także jeden z jego zasadniczych elementów - tatuaż), oraz te, które przyporządkować możemy do kwestii audialnych - oba porządki

22 D. Morozow, Reading My Body, www.vtol.cc/filter/works/reading-my-body (tłum. własne).

23 Główne założenia projektu interpretuje na łamach internetowej wersji magazynu „Neutral” Aurelio Cianciotta: „Historyczny rozwój zachodniej muzyki był opisywany w terminach dotyczących dystansowania się od ciała: identyfikacja muzyki z jej notacją i progresywna automatyzacja instrumentów muzycznych są dwiema stronami tego procesu. Dimitrij Morozow (::vtol::) odwraca tę linearną trajektorię". A. Cianciotta, ::vtol::-Reading My Body, Skin Player, 8.12.2014, www.neural.it/2014/12/ vtol-skin-player/ (tłum. własne).

24 Rola, jaką odgrywało ciało XIX-wiecznego wykonawcy, była znacząca dla efektu całego koncertu. Świetnym przykładem jest Niccolo Paganini, którego postura wzbudzała równie wielkie zdumienie, co jego fenomenalna technika gry: ,Ukazanie się na podium wirtuoza o osobliwym wyglądzie i trochę niepewnym, egzaltowanym zachowaniu się, wywołało na twarzy zebranego towarzystwa najpierw zdumienie, a potem drwiące uśmieszki. Spodziewano się bowiem ujrzeć pewnego siebie, przyzwyczajonego do hołdów, sprawiającego na widzach imponujące wrażenie mężczyznę...”. J. Powroźniak, Paganini, Kraków 1958, s. 32.

25 Zob. G. Fisher, J. Lochhead, Analyzing from the Body, ,Theory and Practice” 2002, nr 27, s. 37-67 (tłum. własne). 
są tu nierozerwalne. Artysta nie traci własnej podmiotowości na rzecz instrumentu, a wręcz nadaje podmiotowość obiektowi, który jest zarówno jego przedłużeniem, ale także interpretatorem. To ciało muzyka jest tu instrumentem, elektroniczna nakładka jedynie kontrolowanym kompilatorem. Morozow jako muzyk stanowi figurę inspirującego i krytycznego wobec swoich własnych czasów cyborga - istoty, która swoje ,bycie” opiera na nieustannym napięciu pomiędzy tym, co ludzkie, i tym, co mechaniczne ${ }^{26}$. Muzyk nie rezygnuje jednak z własnej tożsamości; pozostaje artystą, którego ciało jest newralgicznym elementem instrumentu. Urządzenia, które nadzoruje, i nad którym ma (jeszcze) władzę.

\section{Więcej niż jedno ciało?}

Zaprezentowane obiekty audiowizualne podkreślają istotność ciała, zarówno wykonawcy, jak i odbiorcy (nawet jeżeli jest ono pozornie nieobecne, jak w przypadku Deus Cantando). Jeżeli można powiedzieć, że ::vtol:: problematyzuje kwestie bariery pomiędzy artystą a instrumentem, to projekt Michela i André Décosterd Pendulum Choir dokonuje w tym zakresie transgresji. Opis instalacji dźwiękowej znajdujemy na oficjalnym portalu projektu:

Pendulum Choir jest oryginalnym utworem chóralnym rozpisanym na dziewięć głosów a cappella i osiemnaście hydraulicznych podnośników. Chór stoi na obracanych platformach, tworząc żywe brzmiące ciało. Ciało, które wyraża się przez różnorodne stany fizyczne. Jego plastyczność zmienia się za sprawą łaski (sic!) jego dźwięczności. Jego zmienność waha się od dźwięków abstrakcyjnych przez dźwięki powtarzalne, a także liryczne i narracyjne. Ciała i głosy śpiewaków współgrają, ale także sprzeciwiają się grawitacji ${ }^{27}$.

Akcentowana jest kolektywna forma i rola „ciała”, ale trudno całkowicie pozbyć się wrażenia, że jest (są) w jakiś sposób pozbawione właściwości rozumianych potocznie jako „ludzkie”, co jest najprawdopodobniej efektem zastosowania posthumanistycznej estetyki na potrzeby tego obiektu. Dzięki współczesnej sztuce „wrażeniowość ulega poszerzaniu”, jak pisała o tym Monika Bakke, posiłkując się myślą Wolfganga Welscha:

26 Praca Dimitrija Morozowa aż prosi się o interpretację w duchu Manifestu Cyborga krytyczki kultury i feministki Donny Haraway. Niestety ze względu na inny niż typowo transhumanistyczny charakter tego tekstu nie mogę pozwolić sobie na zbyt obszerne analizy. Warto przywołać jednak kilka fragmentów manifestu, które nawet bez dodatkowego komentarza mogłyby stanowić tekst kuratorski dla pracy Reading My Body: „Cyborg to silnie zagęszczony symbol, składający się w równym stopniu z wyobrażeniowych fantazmatów i materialnej rzeczywistości. (...) relacje między organizmem a maszyną określała wojna o linie podziału. Stawką tego przygranicznego konfliktu były obszary produkcji, rozmnażania i wyobraźni (...). Cyborg z uporem i śmiałością poddaje się fragmentaryzacji, lubi ironię, pozwala sobie na intymność i perwersję. Pociągają go sprzeczne stanowiska oraz utopie, a poza tym nie grzeszy w jakimkolwiek sensie naiwnościq”. D. Harraway, Manifest Cyborga, przeł. E. Franus, „Magazyn Sztuki” 1998, nr 17, źródło: www.magazynsztuki.eu/old/archiwum/post_modern/postmodern_9.htm. Zob. www.codact.ch/gb/pendugb.html. 
Nowe stany aisthesis wynikają więc także z poszerzenia interesującej nas sfery postrzegania o nie-ludzi oraz o hybrydyczne ciała powstałe dzięki technonauce ${ }^{28}$.

Postrzeganie zmysłowe (aisthesis), o którym pisał Welsch (a co w książce Bio-transfiguracje żywo komentuje Monika Bakke), ma być sposobem przeformułowania ludzkiej podmiotowości, która może być w końcu otwarta na najróżniejsze bodźce zmysłowe, również te, które są całkowicie nie-ludzkie lub transludzkie ${ }^{29}$. Niewątpliwie projekt Décosterdów wykracza poza prosty podział na to, co może stanowić instalację wizualną lub dźwiękową, a wręcz transludzką lub opartą na somatoestetyce $^{30}$. To przede wszystkim skomplikowana sytuacja: po pierwsze ciał będących częścią obiektu, a po drugie to moment, w którym staje podmiot percypujący, który zmuszony jest wejść w specyficzną relację z Pendulum Choir ${ }^{31}$. W polu percepcji podmiotu postawiony zostaje obiekt, w którym oprócz elementów mechanizmu rozpoznaje on ciała podobne jemu. Ciała te jednak zaczynają tracić swoje właściwości potencjalnego podmiotowego samostanowienia. Dzieje się to w momencie, w którym rusza mechanizm i rozpoczynają swoje partie chóralne. Klasyczna sytuacja podmiototwórcza $J a-I n n y^{32}$ zostaje zachwiana i dochodzi do transformacji: podmiot wchodzi do porządku relacji Ja - Obiekt. Już samo przejście między formą relacji podmiotowo - podmiotowej na rzecz podmiotowo - przedmiotowej powoduje uczucie dyskomfortu i jednoczesnej fascynacji.

Pendulum Choir to rodzaj maszynerii nieustannie podważających się rozwiązań dźwiękowych i cielesnych, w której podmiot wchodzi w proces sedymentacji $^{33}$ sensów percypowanych obiektów: ustala porządek, od biologicznych ciał, aż do mechanicznych elementów maszyny. Następnie na powrót musi uznać, że chór jest holistycznym obiektem (instrumentem), w którym każde z dziewięciu ciał nie ma znaczenia większego niż wyłącznie instrumentalne, a jest to konieczne, by uznać instalację za jednorodny obiekt artystyczny. W kolejnej chwili podmiot może uznać, że każdy głos (ale już nie to kolektywne audio-ciało) jest jednak indywidualny; zależnie od pozycji platformy, na której się znajduje. Instalacja staje się

28 M. Bakke, Bio-transfiguracje. Sztuka i estetyka posthumanizmu, Poznań 2015, s. 200.

29 Zob. ibidem, s. 200-204.

30 Zob. R. Shusterman, Świadomość ciała..., op. cit.

31 Być może to właśnie w tym dziele odnajdujemy prawdziwe (bowiem pozbawione indywidualnych cech) ciało w śpiewającym głosie lub ,ziarno głosu”, o którym pisał Roland Barthes? Zob. R. Barthes, Ziarno glosu, przeł. J. Momro, „Teksty Drugie” 2015, nr 5, s. 229-237.

32 Ze względu na brak miejsca na dokładne opisanie zróżnicowanych założeń filozofii spotkania wszystkich zainteresowanych kwestią relacji Ja i Inny odsyłam do takich pozycji bibliograficznych, jak: E. Lévinas, Istniejący i istnienie (przeł. J. Margański, Kraków 2006) czy M. Buber, Ja i Ty (przeł. J. Doktór, Warszawa 1992). Stanowią idealne wprowadzenie do procesów podmiototwórczych w sytuacji spotkania z innym człowiekiem.

33 Stosuję tu pojęcie sedymentacji, jako formy bezwładnego rozwarstwiania elementów sensotwórczych, które w każdym momencie mogą zostać na nowo połączone w semiotyczną zawiesinę - pewien określony dla podmiotu stan pewności wobec percypowanej rzeczywistości, oczywiście iluzorycznej. 
na powrót zbiorem ciał śpiewaków. Wszystko w tym projekcie wydaje się ruchome oraz rozciągłe czasowo i przestrzennie. Problemem podmiotu jest to, że tylko on w tej sytuacji pozostaje obiektem statycznym, który zdolny jest wyłącznie do percepcji dźwiękowej i wizualnej. Ciała, które raz wydają się podmiotowe, by za chwilę stać się tylko obiektem lub jego częścią - tym samym nieustannie podważają stabilność poznawczą podmiotu.

\section{Orkiestracja ciała czy somatyzacja instrumentu? Audio-soma-wizualność}

Wszystkie trzy projekty zdają się podważać ideę audiowizualności opartej wyłącznie na (wpisanym w samą nazwę pojęcia) doświadczeniu obrazowym i dźwiękowym. Być może więc podstawową kwestią, wyjętą wprost z perspektywy muzykologicznej, byłaby ta dotycząca relacji pomiędzy orkiestracją a somatyzacją oraz ciszą i dźwiękiem? Na ile ciało da się orkiestrować i tym samym dyscyplinować partyturą $^{34}$, a na ile można ucieleśnić instrument muzyczny? Pendulum Choir i Reading My Body wydają się udowadniać, że oba akty są tym samym działaniem i nie da się ich od siebie odseparować. Deus Cantando subtelnie wprowadza odbiorcę w problematykę braku i obecności; a więc ciszy i dźwięku oraz ich konsekwencji dla słuchacza/widza. Wchodząc w relację z prezentowanymi obiektami, jesteśmy zmuszeni do uznania lub próby podważenia pewnej określonej relacji władzy. Wszystkie trzy projekty to wytrącające podmiot $\mathrm{z}$ równowagi machiny somatoestetyczne, niestrudzone w projektowaniu i podważaniu fundamentalnych dla odbiorcy sensów, a to znacznie więcej, niż pozwala w interpretacji porządek audiowizualny.

Mówienie o klasycznej audiowizualności zakładałoby bowiem projektowanie dwóch zbiorów analiz: dźwiękowej i wizualnej, które w czasie deskrypcji danego zjawiska oddalają się od siebie, by w podsumowaniu połączyć się niestabilnymi mostami wzajemnych powiązań. Niewątpliwie w takim ujęciu audiowizualność jest konstrukcją złudną. Tak rozumiana audiowizualność to utopia, która łudzi nas równouprawnieniem i samostanowieniem dźwięku i obrazu. Tym samym dochodzimy do punktu, w którym albo mówimy o dźwięku bez obrazu lub o obrazie bez dźwięku i pozostawiamy oba pola rozdzielne, albo próbujemy wejść w myślenie audiowizualne z wpisaną w ten namysł porażką niekoherentności obu języków (o czym wyżej wspominałem, przywołując tekst Jakuba Momro). Jeżeli chcemy mówić o dźwięku i obiektach dźwiękowych, niekoniecznie separując je od ich potencjalnych aspektów wizualnych, to być może warto inaczej postawić pytania o charakter audiowizualności lub też całkowicie zrezygnować z tego pojęcia na rzecz podmiotów percypujących i obiektów percepcji. Przy okazji prezentacji prac Ablingera, Morozowa i Déco-

34 Dyscyplinowanie ciała oczywiście rozumiem w perspektywie foucaultowskiej, zob. M. Foucault, Nadzorować i karać. Narodziny więzienia, przeł. T. Komendant, Warszawa 2009. 
sterdów da się zauważyć, że mowa tu o podmiotach doświadczających za pomocą nie wzroku, czy słuchu, a raczej całego sensorium - dla którego rodzajem pośrednika pomiędzy zmysłami a obiektami jest ludzkie ciało. Dzięki temu możliwa jest analiza oparta na relacji zachodzącej między obiektem dźwiękowym/wizualnym, podmiotem percypującym i przestrzenią, w której znajduje się doświadczający podmiot. W takim ujęciu relacja podmiot - obiekt okazuje się ani wyłącznie audialna, ani wizualna, a próba analizy takiego doświadczenia z tylko jednej perspektywy, obrazowej bądź dźwiękowej, jest cięciem epistemicznym. Ciało, wchodząc w relację z obiektem dźwiękowym/wizualnym, uruchamia całe swoje senorium - rozciąga swą materię na potencjał doświadczenia, jak ująłby to Jean-Luc Nancy ${ }^{35}$. Jak bardzo złożone jest to doświadczenie i jak nieustannie przesuwana jest granica pomiędzy tym, co cielesne, wizualne i dźwiękowe (a także tymi elementami, które angażują pozostałe zmysły), udowadniają nam artyści, których awangardowe projekty uderzają wprost w monumentalny podział pomiędzy tym, co przynależne ciału, dźwiękowi i obrazom. Muzyczne eksperymenty Petera Ablingera, Dimitrija Morozowa czy projekt Pendulum Choir angażują doznania percepcyjne i cielesne, a tym samym otwierają klasycznie rozumianą zmysłowość na zupełnie nowy wymiar doświadczenia. Rozszerzenie percepcji podmiotu o aspekty somatyczne, zarówno fantomowo, jak i całkowicie realnie, następuje przy jednoczesnym wykorzystaniu dźwięków i obrazów. Jak pisali o tej kwestii George Fisher i Judy Lochhead w swoim przełomowym dla refleksji muzyczno-somatycznej artykule Analyizing from the Body:

Dla słuchacza oglądanie występu muzycznego, zamiast jedynie słuchania [go], przyczynia się nie tylko do zwiększenia wartości muzycznej rozrywki, ale także do lepszego zrozumienia utworu: interakcja pomiędzy komponentami wizualnymi i aurą [dzieła muzycznego] stwarza możliwie najpełniejsze doświadczenie muzyczne ${ }^{36}$.

Deus Cantando, Reading My Body i Pendulum Choir to nie tylko intrygujące zjawiska akustyczne, problematyzujące kwestie źródła głosu, to także obiekty audiowizualne, które wikłają odbiorcę w relację polityczną ${ }^{37}$, w której ciało (lub jego brak) jest główną jednostką dystrybutywnej wymiany sensów i ustaleń ontologicznych: czy to, co widzę, jest ciałem? Czym to ciało różni się od mojego? W jakim stosunku pozostaję z tym ciałem? itd. Oznacza to, że podmiot (który, zgodnie z teorią Merleau-Ponty’ego, doświadcza świata wyłącznie za pośrednictwem ciała) zmuszony jest negocjować dotychczasowo stabilne schematy somatyczne, które wytworzył i przysto-

35 Zob. J.-L. Nancy, Corpus, przeł. M. Kwietniewska, Gdańsk 2002.

36 G. Fisher, J. Lochhead, Analyzing from the Body, op. cit., s. 46-47 (tłum. własne).

37 Polityczność rozumiem tu w perspektywie rancière'owskiej, czyli jako zbiór społecznie ukonstytuowanych prawideł, wobec których ustalamy kategorie: tego, co i jak widzimy, co możemy o tym następnie powiedzieć, oraz zasady: tego, kto ma kompetencje, aby widzieć i predyspozycje, aby o tym mówić, oraz sposoby zajmowania, dzielenia przestrzeni lub dysponowania czasem w określonych sytuacjach społecznych. Por. J. Rancière, Dzielenie postrzegalnego, przeł. J. Sowa, Kraków 2007, s. 59-94. 
sował do znanych mu dotychczas sytuacji obcowania z tekstami audiowizualnymi, wabiącymi go dźwiękiem i obrazem. Dopiero namysł sensoryczny oraz ulokowanie siebie jako cielesnego podmiotu w stosunku do obiektu ukazuje nam złożoność tych dzieł, które jawią się jako krytyczne instalacje, w których aspekt dźwiękowy jest równie istotny jak element wizualny, oczywiście w wyniku relacji do ciała odbiorcy. Jak widać, przez ukazanie braku, fragmentu lub nadmiaru ciała możemy czasem usłyszeć głos, którego nigdy nie zamierzaliśmy słuchać. Warto, by audiowizualność zyskała nowy aktant - ciało, które zdaje się spajać i wypełniać szczeliny między językiem dźwięków i językiem obrazów. Przedstawiając powyższe projekty, w których aspekt wizualny, jak i audialny jest równie istotny, chciałem zaproponować własną propozycję badania audiowizualności jako zjawiska na wskroś somatycznego. Do triady podmiot - dźwięk - obraz konieczne wydaje się dodanie elementu ciała: zarówno odbiorcy, jak i wykonawcy. Dzięki temu wejdziemy w dyskurs sensoryczny, który pozwala podmiotowi na podjęcie walki o zrozumienie i przeżycie estetycznej przyjemności z dziełami, które angażują całe ciało oraz zmysły w procesie percepcji. Oko i ucho to tylko narzędzia ciała, które syntezuje bodźce dźwiękowe i wizualne. Tym samym proponuję rozważyć pracę nad nowymi narzędziami koniecznymi do analizy współczesnych zjawisk i testów kultury opartych na doświadczeniach dźwiękowych i obrazowych: narzędziami audio-soma-wizualnymi.

\section{Bibliografia}

Bakke M., Bio-transfiguracje. Sztuka i estetyka posthumanizmu, Poznań 2015.

Barthes R., Ziarno głosu, przeł. J. Momro, „Teksty Drugie” 2015, nr 5.

Benjamin W., Twórca jako wytwórca, przeł. R. Reszke, Warszawa 2011.

Berleant A., Wrażliwość i zmysty. Estetyczna przemiana świata człowieka, przeł. S. Stankiewicz, Kraków 2011.

Buber M., Ja i Ty, przeł. J. Doktór, Warszawa 1992.

Cianciotta A., ::vtol:: - Reading My Body, Skin Player, 8.12.2014, www.neural.it/2014/12/ vtol-skin-player/ (tłum. własne).

Deleuze G., Fałda: Leibniz a barok, przeł. M. Janik, Warszawa 2014.

Dolar M., Voice and Nothing More, Cambridge 2006 (tłum. własne).

Fisher G., Lochhead J., Analyzing from the Body, „Theory and Practice” 2002, nr 27.

Foucault M., Nadzorować i karać. Narodziny więzienia, przeł. T. Komendant, Warszawa 2009.

Gould G., The Prospects of Recording, w: Glenn Gould Reader, New York 1984.

Harraway D., Manifest Cyborga, przeł. E. Franus, „Magazyn Sztuki” 1998, nr 17.

Howes D., A Cultural History of the Senses in the Modern Age, 1920-2000, London-New York 2014.

Howes D., Sensual Relations: Engaging the Senses in Culture and Social Theory, Ann Arbor 2003.

Husserl E., Doświadczenie i sad: badania nad genealogia logiki, przeł. B. Baran, Warszawa 2013.

Jelewska A., Sensorium. Eseje o sztuce i technologii, Poznań 2012. 
Lehmann H., Muzyka relacyjna, artykuł cyfrowy, źródło: www.rewolucjacyfrowa.beczmiana.pl. Lévinas E., Istniejący i istnienie, przeł. J. Margański, Kraków 2006.

McNiff S., Art-Based Research, w: J.G. Knowles, A.L. Cole, Handbook of the Arts in Qualitative Research: Perspectives, Methodologies, Examples, and Issues, Thousand Oaks 2008.

Merleau-Ponty M., Fenomenologia percepcji, przeł. M. Kowalska, J. Migasiński, Warszawa 2001.

Mitchell W.J.T., Czego chca obrazy? Pragnienia przedstawień, życie i miłości obrazów, przeł. Ł. Zaremba, Warszawa 2015.

Momro J., Fenomenologia ucha, „Teksty Drugie” 2015, nr 5.

Morozow D., Reading My Body, www.vtol.cc/filter/works/reading-my-body (thum. własne).

Nancy J.-L., Corpus, przeł. M. Kwietniewska, Gdańsk 2002.

Noë A., Action in Perception, Cambridge 2002.

Powroźniak J., Paganini, Kraków 1958.

Rancière J., Dzielenie postrzegalnego, przeł. J. Sowa, Kraków 2007.

Rieger S., Glenn Gould, czyli sztuka fugi, Gdańsk 1997.

Schaeffer P., Akuzmatyka, w: C. Cox, D. Warner, Kultura dźwięku. Teksty o muzyce nowoczesnej, przeł. J. Kutyła, Gdańsk 2010.

Shusterman R., Świadomość ciała. Dociekania z zakresu somaestetyki, przeł. W. Małecki, S. Stankiewicz, Kraków 2016.

Stanisz A., Audioantropologia: praktykowanie dyscypliny poprzez dźwięk, „Zeszyty Naukowe Uniwersytetu Jagiellońskiego MCCCXXXVI. Prace Etnograficzne” 2014, t. 42, z. 4.

Sterne J., Audible Past: Cultural Origins of Sound Reproduction, London 2003.

Young I.M., Throwing Like a Girl: A Phenomenology of Feminine Body Comportment Motility and Spatiality, „Human Studies” 1980, nr 3. 